\title{
Research and Development of Silvopastoral Systems in a Village in the Buffer Zone of the El Ocote Biosphere Reserve, Chiapas, Mexico
}

\author{
${ }^{1} \mathrm{~J}$. Nahed-Toral, ${ }^{2} \mathrm{H}$. Gomez-Castro, ${ }^{2} \mathrm{R}$. Pinto-Ruiz, ${ }^{2} \mathrm{~F}$. Guevara-Hernandez, \\ ${ }^{2} \mathrm{~F}$. Medina-Jonapa, ${ }^{3} \mathrm{M}$. Ibrahim and ${ }^{4} \mathrm{D}$. Grande-Cano \\ ${ }^{1}$ El Colegio de la Frontera Sur, Carretera Panamericana y Periferico Sur s/n, 29290, \\ San Cristobal de Las Casas, Chiapas, Mexico \\ ${ }^{2}$ Facultad de Ciencias Agronomicas, Universidad Autonoma de Chiapas, \\ Tuxtla Gutierrez, Chiapas, Mexico \\ ${ }^{3}$ Centro Agronomico Tropical de Investigacion and Ensenanza, Turrialba, Costa Rica, Maxico \\ ${ }^{4}$ Area de Sistemas de Production Agropecuarios, Division de Ciencias Biologicas y de la Salud, \\ Universidad Autonoma Metropolitana Iztapalapa, Mexico City, D. F., Mexico
}

\begin{abstract}
A participatory research and development project in establishment of agrosilvopastoral systems was documented. This study was carried out in the village Tierra Nueva (TN), located in the Buffer zone of the El Ocote Biosphere Reserve (EOBIRE) in the state of Chiapas, Mexico. This zone is part of the area of influence of the Mesoamerican Biological Corridor in Mexico (MBCM). A variety of methods related to agroforestry were used, along with the Farmer Field Schools Methodology by which producers may develop new aptitudes and knowledge regarding cattle raising and conservation. The bovine production system and productive diversification of cattle raising units were analyzed. Grazing units are characterized and their carrying capacity estimated. Chemical-nutritional composition and ruminal degradation of foliage is characterized for woody fodder species. Finally, the experience is projected to the future in order to strengthen local innovation processes.
\end{abstract}

Key words: Silvopastoral systems, cattle production, woody fodder plants, participatory research, Chiapas, compostion

\section{NTRODUCTION}

The widespread introduction of cattle raising in tropical and subtropical areas of most Latin American countries as a result of the neoliberal model of development has brought about expansion of pastures at the expense of forests and jungles, loss of biodiversity, low animal productivity, soil degradation and socioeconomic polarization. Due to these negative consequences, this process has been a research priority for academic institutions (Delgado et al., 1999; Steinfeld, 2002). The debate regards which development strategies to follow in order to transform extensive cattle raising toward sustainable cattle raising in order to reconcile improvement of current productive systems and natural resource conservation; obtain greater biological and economic efficiency and greater self-sufficiency in production of meat, milk, wool and sub-products of animal origin and favor equity among producers (Speeding, 1995; Nahed-Toral, 2006). Agrosilvopastoral systems as a type of agroforestry: contribute to maximizing positive interactions among crop agriculture, cattle raising, silviculture and the physical environment, maximize productivity of the land, allow for efficiently manipulating biological principles of animal and plant production and their interactions increase production, promote a balance between use and conservation of natural resources and favor sustainable development of resources (Russo, 1996; Nahed et al., 1998; Dagang and Nair, 2003). After 30 years of formal studies in silvopastoral and agrosilvopastoral systems as examples of agroforestry, these have gained importance worldwide. A variety of conferences, workshops, symposiums and congresses have allowed for sharing experiences regarding how to improve animal production in silvopastoral systems. The possibilities of success of silvopastoral systems increase when the development process consecutively includes the stages of:

Corresponding Author: D. Grande-Cano, Av. San Rafael Atlixco 186 Col. Vicentina, Delegacion Iztapalapa, C.P. 09340, Mexico City, D. F., Mexico 
- Diagnostic study and analysis of prevalent systems

- Innovation and design of technologies and social-environmental processes

- Management and evaluation

- Monitoring of the process (Jimenez-Ferrer et al., 2005; Nahed et al., 2003)

Evaluating the level of progress and identifying limits, potentials and opportunities observed at each stage are parts of the process of development and allow for continuing or pausing in order to solve problems.

According to the classification of agroforestry systems proposed by Nair (1993) in the state of Chiapas, a variety of types of traditional agroforestry systems have existed. Esponda (1988) was probably the first in the state to carry out reproduction trials of tree species in order to establish living fences and other agronomic arrangements. Currently, cattle raising in rural communities of the Mesoamerican Biological Corridor in Chiapas in particular those located within the buffer zones of the natural protected areas of Montes Azules, El Ocote, La Sepultura, El Triunfo and La Encrucijada are managed under traditional agrosilvopastoral systems.

Grazing is integrated into agricultural production and is carried out in grazing units with a tree gradient ranging from extensive pastures (without trees) to pastures with live fences, shrubs and/or fallows, dispersed trees and forested areas used in an alternating manner throughout the annual cycle.

Since, the 1990's valuable information has been published regarding the diverse stages of research and development of agrosilvopastoral systems in Chiapas. Studies have principally addressed topics of local knowledge uses, distribution, abundance and agroecological requirements of species of fodder shrubs and trees in a variety of regions of Chiapas; production of biomass and chemical-nutritional analysis of the foliage; consumption, digestibility, ruminal degradability and biological response of animals supplemented with foliage from woody fodder species; agronomic practices and environmental services.

With this in mind the objective of the current study is to synthesize the principal results of the process of research and development of silvopastoral systems in the village Tierra Nueva, located in the Buffer zone of the El Ocote Biosphere Reserve (EOBIRE) in Chiapas, Mexico. As in other buffer zones of natural protected areas of Chiapas, this zone is populated by rural small-scale agricultural producers. To a certain extent, the producers are object of institutional imposed legal restriction in use of natural resources and the lack of employment opportunities (Vasquez et al., 1996). Under this situation they opt for cattle raising in order to subsist. Thus, jungles are continually being replaced by expanding pastures in order to maintain increasing herd sizes.

Silvopastoral systems are a viable option for buffer zones of natural protected areas as they improve animal productivity, allow for converting extensive cattle raising toward sustainable systems compatible with natural resource protection and contribute to detaining deforestation in still conserved areas.

\section{MATERIALS AND METHODS}

Location and characteristics of the study area: The current study was carried out in the Ejido (collective land holding), Tierra Nueva in the buffer zone of EOBIRE, in Western Chiapas. The reserve lies between $16^{\circ} 45^{\prime} 42^{\prime \prime}$ and $17^{\circ} 09^{\prime} 00^{\prime \prime}$ North latitude and $93^{\circ} 54^{\prime} 19^{\prime \prime}$ and $93^{\circ} 21^{\prime} 20^{\prime \prime}$ West longitude. Climate is semi-warm subhumid (total annual precipitation of $1,200-1,500 \mathrm{~mm}$ ) to warm-humid (total annual precipitation of $2,000-2,500 \mathrm{~mm}$ ) with greater precipitation from June to October. Median annual temperature is $18-22^{\circ} \mathrm{C}$ (May and June are the warmest months) and altitude ranges from de 600-1,500 masl.

Techniques and methods used: In order to analyze Bovine production systems and productive diversification of the cattle raising units, information was obtained through direct observation of the cattle farms and a questionnaire applied to producers using the semi-structured informal interview (Gillham, 2005).

Types of grazing units were classified and characterized according to tree density using the methodology proposed by Perez (2006). A village map was used to locate pastures. Three participatory workshops were carried out, 6 key informants were interviewed and 5 linear transects were explored in order to directly observe 41 grazing units.

Net Aerial Primary Production (NAPP): Live matter plus dead standing matter of pastures with Brachiaria brizantha was evaluated between July and November at different cutting times (15, 30 and 45 days) during the rainiest season using the 't Mannetje method (Mannetje, 1978). NAPP information was used in order to estimate carrying capacity of cattle raising for the area.

A diversity of woody fodder species in the zone were documented in a participatory workshop and confirmed in the field. Chemical-nutritional characteristics and ruminal degradability of fodder of promissory species were evaluated using the AOAC (1995) and Mehrez and Orskov (1977) methods, respectively. The silvopastoral systems were implemented through the farmer Field 
schools methodology (Minjauw et al., 2002) in Tierra Nueva and the projection of the future study in order to strengthen local capabilities was based on studies of Guevara et al. (2003) and Guevara-Hernandez et al. (2008).

\section{RESULTS AND DISCUSSION}

Analysis of Bovine production systems and diversification of cattle raising units: In the Ejido Tierra Nueva, cattle are raised under traditional agrosilvopastoral management, characterized by use of pastures with different levels of tree density, varying histories of use, crop associations with basic foods (principally maize and beans), rotation of crops, pastures and fallows and use of foliage of fodder trees and shrubs in forested areas. Low levels of technological development and investment of capital are evidenced in:

- Use of family labor

- Precarious installations

- Use of manual labor

- Lack of basic infrastructure (roads, electricity and water)

- Low level of integration between production and marketing

Similar situations have been reported for cattle raising systems in other countries as well (Mahadevan, 1984). Specific characteristics of cattle raising in Tierra Nueva are shown in Table 1. Producers are principally young adults with a maximum educational level of primary school. Compared to older producers, they have shown greater openness to receiving training and interest in technological innovations. Thus, they represent an opportunity for development of agrosilvopastoral systems. With respect to access to land, there is great variation in surface area of agricultural, pasture and fallow land and thus in total land surface per producer. The general tendency is that the greater the surface of pasture lands, the greater the herd size-expressed in head of cattle and/or standardized in animal units. Average herd size is relatively small, suggesting that actual animal load is below than the carrying capacity of the grazing units. Nevertheless, the fact that producers plan to increment their herd size and incorporation of new Ejido members into cattle raising indicate that pressure on the jungle in order to increase grazing area will increase.

In Tierra Nueva, cattle raising is just a small part of the diversity of productive activities. Families obtain an average of $\$ 50,316.00( \pm \$ 13,885.00)$ total annual income (in Mexican Pesos, equivalent to $\$ 3,993$ USD or $\$ 3,031$ Euros).
Table 1: Some characteristics of campesino cattle raising in the Ejido Tierra Nueva in the buffer zone of the $\mathrm{El}$ Ocote biosphere reserve $(\mathrm{N}=21$ producers $)$

\begin{tabular}{lcrrr}
\hline & & \multicolumn{3}{c}{ Maximum } \\
Variables & Average & SE $( \pm)$ & \multicolumn{1}{c}{ value } & value \\
\hline Producer age (years) & 37.80 & 12.00 & 60.00 & 22.0 \\
Total land surface (ha) & 13.40 & 5.50 & 32.00 & 6.5 \\
Agricultural surface (ha) & 4.10 & 2.30 & 10.50 & 1.5 \\
Surface of pasture and fallow (ha) & 9.30 & 4.90 & 25.00 & 3.5 \\
Herd size (number of cattle) & 10.60 & 4.50 & 18.00 & 4.0 \\
Animal units (number) & 7.30 & 3.50 & 15.60 & 2.0 \\
Animal load (AU ha ${ }^{-1}$ of pasture) & 0.68 & 0.09 & 0.87 & 0.5 \\
Domestic fowl (number) & 10.90 & 9.50 & 33.00 & 0.0 \\
\hline
\end{tabular}

Sources and proportions of income are:

- Cattle raising: $20.67 \%$

- Other farm animals: $4.27 \%$

- Fruits and vegetables: $7.65 \%$

- Maize: $4.97 \%$

- Coffee: $6.38 \%$

- Beans: $3.14 \%$

- Migrant remittances: $10.56 \%$

- PROCAMPO (Program of direct financial support to rural areas): $18.15 \%$

- Opportunities (financial support to families with children attending school): $18.84 \%$

- PRODERS (Program of sustainable rural development): $4.47 \%$

- Program of temporary employment: $1.26 \%$

Thus, productive activities as a whole make up $47.08 \%$ of producer family income while remittances and governmental support makes up $52.92 \%$ of average annual family income.

The fact that cattle raising contributes $20.67 \%$ to total family income and $42.65 \%$ to agricultural income motivates agricultural producers to raise cattle. Cattle raising has become the most important productive activity in economic terms for Ejido members, placing on second term agricultural activities. Therefore, cattle raising threatens natural resource conservation, as pointed out by Vasquez et al. (1996) and thus it has become necessary to foment development of integrated, intensive agrosilovpastoral systems with low use of external inputs (Nahed et al., 1998). Objectives of converting conventional cattle raising toward sustainable, natural resource-friendly systems include:

- Halting deforestation in still-conserved areas

- $\quad$ Promoting value added with healthy animal products which are competitive quality-wise with conventionally produced products

- Improving the quality of life of producers and their families 
Table 2: Density of tree species in 3 types of grazing units and frequency of each species in 5 transects in the village Tierra Nueva Density of tree species (trees hat ${ }^{-1}$ )

\begin{tabular}{lccccc} 
Grazing & & - & --------- & \\
unit & Number & Average & Maximum & Minimum & Frequency (\%) \\
\hline GULTD & 10 & 28 & 29 & 26 & 24 \\
GUMTD & 22 & 93 & 100 & 85 & 54 \\
GUHTD & 9 & 163 & 170 & 155 & 22 \\
\hline
\end{tabular}

GULTD: Grazing Unit with Low Tree Density; GUMTD: Grazing Unit with Medium Tree Density; GUHTD: Grazing Unit with High Tree Density

Grazing units and carrying capacity of cattle raising: In order to plan cattle raising sustained in grazing, it is important to identify types of grazing units (grassland or pasture) and quantity of forage which these provide. This information is essential to precisely regulating grazing intensity (No. of animals $\mathrm{ha}^{-1}$ ) and frequency (days of grazing and rest) (Trlica and Rittenhouse, 1993; Lopez-Tirado and Jones, 1991).

Three types of grazing units are shown in Table 2 . Grazing units of medium tree density predominated and added to high tree density grazing units, made up $76 \%$ of all grazing units. The current high tree density of the village studied could be due to the fact that conversion of the jungle to cattle raising is recent and has been gradual and therefore, local forests are still highly conserved. Nevertheless, the tendency to increase herd size and the greater number of producers who are beginning to raise cattle are leading to an increase in grazing units with low tree density. This situation was particularly observed near the neighboring community of Francisco I. Madero. In this area, grazing units with high tree density are the least frequent. They predominate in areas planted with coffee, due to the fact that producers are aware of the benefits of shade in coffee plantations and also because they maintain shady areas for well-being of cattle and care of grasses.

Tree composition of the three grazing units principally consisted of citruses such as orange (Citrus cinensis) and mandarin orange (Citrus aurantium) and woody fodder species such as caulote (Guazuma umifolia), cocoite (Gliricidia sepium) and guash (Leucaena leucocephala).

Of the graminae found in the grazing units, B. brizantha made up $85 \%$; Cynodon plectostachyus made up $10 \%$ and native grasses $5 \%$. With a cutting frequency of 15 days, results of the evaluation of grazing units with $B$. brizantha showed a tendency $(\mathrm{p}<0.05)$ toward greater primary production of this species in the 3 types of grazing units (Table 3 ). Grazing units with medium tree density favored a relatively greater primary production of $B$. brizantha in all three cutting frequencies.

Based on primary production in grazing units with different cutting frequencies and an assignation of $5 \%$ of live weight of the animals of daily consumption of dry
Table 3: Net aerial primary production $\left(\mathrm{kg} \mathrm{DM} \mathrm{ha}^{-1}\right)$ of Brachiaria brizantha in 3 types of grazing units and 3 cutting frequencies in the village Tierra Nueva

\begin{tabular}{llll}
\hline & \multicolumn{1}{c}{ Frequency of cutting $($ days $)$} & \\
Grazing & \multicolumn{1}{c}{30} & \multicolumn{1}{c}{45} \\
\hline unit & \multicolumn{1}{c}{15} & $9.641(\mathrm{n}=8)$ & $10.392(\mathrm{n}=6)$ \\
GULTD & $8.531(\mathrm{n}=18)$ & 2.544 & 2.043 \\
SE $( \pm)$ & 1.172 & $10.817(\mathrm{n}=8)$ & $13.878(\mathrm{n}=5)$ \\
GUMTD & $9.290(\mathrm{n}=17)$ & 2.057 & 2.150 \\
SE $( \pm)$ & 1.181 & $8.133(\mathrm{n}=7)$ & $9.123(\mathrm{n}=5)$ \\
GUHTD & $7.709(\mathrm{n}=17)$ & 1.516 & 2.315 \\
SE $( \pm)$ & 1.098 &
\end{tabular}

GULTD: Grazing Unit with Low Tree Density; GUMTD: Grazing Unit with Medium Tree Density; GUHTD: Grazing Unit with High Tree Density

Table 4: Carrying capacity (AU ha ${ }^{-1}$ ) of Brachiaria brizantha in 3 types of grazing units and 3 cutting frequencies in the village of Tierra Nueva

Frequency of cutting (days)

\begin{tabular}{llll} 
Grazing unit & 15 & 30 & 45 \\
\hline GULTD & 0.95 & 1.07 & 1.15 \\
GUMTD & 1.03 & 1.20 & 1.54 \\
GUHTD & 0.86 & 0.90 & 1.01 \\
\hline
\end{tabular}

GULTD: Grazing unit with low tree density. GUMTD: Grazing unit with medium tree density. GUHTD: Grazing unit with high tree density

matter, greater carrying capacity was found in grazing units with medium density of trees and a cutting frequency of 45 days (Table 4). Upon comparing carrying capacity of the grazing units in Tierra Nueva and producer demand for forage according to herd size, it was found that $45 \%$ of producers over utilize, $43 \%$ under utilize and only $12 \%$ use the grazing units appropriately. Nevertheless, the current average estimated animal load (of 1.34 $\mathrm{AU} \mathrm{ha}^{-1}$ with $18.2 \pm 8.4$ days of grazing and $36.1 \pm 9.8$ days of rest) is within the range of carrying capacity of 1-1.3 $\mathrm{AU} \mathrm{ha}^{-1}$ established by SAGARPA (2003) for the study area.

Diversity of woody fodder species, chemical-nutritional characteristics and ruminal degradability of foliage Diversity of tree species: In the area of influence of the buffer zone of the EOBIRE, producers have broad empirical knowledge of diversity and traditional uses of woody fodder tree species consumed by animals. The species showed in Table 5 stand out. Silvopastoral knowledge and practices such as pastures in rows of African star grass (Cynodon plectostachyus) with guash (L. leucocephala) or protein banks of guash (L. leucocephala) with cocoite ( $G$. sepium) have acquired importance in the study area during the past decade.

Chemical-nutritional characteristics: Table 5 shows the chemical composition of 6 promissory woody fodder species present in villages in the EOBIRE. There is great variation in chemical composition among these species. G. sepium and L. collinsii stand out due to their high 
Res. J. Biol. Sci., 5 (7): 499-507, 2010

Table 5: Chemical composition (\% in dry base) of foliage of trees and shrubs of greatest forage use in communities in the El Ocote nature reserve, Chiapas,

\begin{tabular}{|c|c|c|c|c|c|c|c|}
\hline Species & $\mathrm{RP}$ & A & $\mathrm{OM}$ & NDF & $\mathrm{ADF}$ & TP & $\mathrm{CT}$ \\
\hline Guazuma ulmifolia & 11.30 & 13.70 & 86.00 & 42.50 & 29.50 & 2.80 & 4.70 \\
\hline Gliricidia sepium & 25.40 & 10.60 & 89.00 & 38.50 & 24.70 & 0.30 & 0.00 \\
\hline Acacia milleriana & 15.85 & 8.50 & 91.50 & 42.70 & 28.50 & 3.50 & 7.30 \\
\hline Leucaena collinsii & 20.10 & 10.10 & 89.80 & 27.50 & 19.10 & 0.30 & 12.80 \\
\hline Erythrina goldmanii & 25.32 & 12.00 & 88.00 & 43.10 & 28.80 & 0.60 & 0.15 \\
\hline Bauhinia ungulata & 13.20 & 7.20 & 92.80 & 42.40 & 26.50 & 4.20 & UD \\
\hline Averages & 18.50 & 10.35 & 89.51 & 39.45 & 26.18 & 1.95 & UD \\
\hline
\end{tabular}

RP: Raw Protein, A: Ash, OM: Organic Matter, NDF: Neutral Detergent Fiber, ADF: Acid Detergent Fiber, TP: Total Phenols, CT: Condensed Tannins, UD: Undetermined

Raw Protein (RP) values and low fiber content. No clearly defined tendency was found in terms of RP among species evaluated, especially in the leguminous species, since $A$. milleriana and B. ungulata showed low values similar to other species.

The majority of foliages evaluated showed high RP levels with an average of $18.52 \%$ (Table 5 ). This greatly surpassed RP content of regional grasses whose average $\mathrm{RP}$ reported is $6.5 \%$ (Pinto, 1995) and which normally do not exceed 10\% RP and 45-60\% digestibility (Leng, 1986). G. sepium and E. goldmanii had the greatest RP values. Nevertheless, the 5 leguminous species evaluated showed $\mathrm{RP}$ values $>12 \%$ which is recommended by some researchers for woody fodder species and therefore, they recommend inclusion of these species in regional silviculture.

Average values of the components of fiber in foliages were intermediate $(\mathrm{NDF}=39.45 \% ; \mathrm{ADF}=26.18 \%)$ with a broad range of variation as observed in other studies of foliage of woody species (Rittner and Reed, 1992; Khazaal et al., 1994). The importance of these values lies in the fact that high $\mathrm{ADF}$ concentration is associated with low digestibility at the ruminal level while high NDF concentration is related to lesser feed consumption (Mupangwa et al., 2000). L. collinsii had the lowest fiber content. With respect to the content of anti-nutritional factors in the foliage, L. collinsii and A. milleriana stood out with respect to condensed tannins and Bauhinia ungulata with respect to total phenols and thus may have adverse affects in ruminants as reported by Kaitho (1997). Meanwhile, the 3 remaining woody forage species have low concentrations of anti-nutritional factors (Table 5).

Ruminal degradability: In order to obtain more information by which to select foliage of woody species with greater forage potential, ruminal degradability was evaluated. Results indicate that $L$. collinsii has the greatest proportion of foliage fermented in the rumen $(81.0 \%)$ and is best absorbed/digested by cattle. It also reaches a degradation rate of $3 \% \mathrm{~h}^{-1}$ which indicates its importance as a possible source of nutrients if permanence in the rumen is not a limiting factor. By contrast, A. milleriana foliage had the least proportion of foliage fermented in the rumen $(67.5 \%)$ and therefore is least absorbed by cattle (Kaitho, 1997). The other species had intermediate proportions of foliage fermented in the rumen and digestibility (G. sepium ,77.6\%; E. goldmanii, $70.8 \%$ and G. ulmifolia, 77.7\%) (Pinto et al., 2006).

Producer knowledge, chemical analysis and ruminal degradability indicate native shrub and tree species with potential as forage species in the development of silvopastoral systems in the study region. Foliage of L. collinsii and G. ulmifolia fruits of E. cyclocarpum and G. ulmifolia stand out. Currently, these species are being agronomically evaluated in order to systematically introduce them into ruminant production systems.

An example of local innovation of cattle raising through silvopastoral systems in the Ejido Tierra Nueva: Table 6 shows a chronological synthesis of the process of developing silvopastoral systems in the community Tierra Nueva. Practical application of the results mentioned in this document was initiated in 2003. This innovation process began with a workshop organized by the Secretary of Rural Development of the state of Chiapas in coordination with the Agronomic Center for Research and Teaching (CATIE), the College of the Southern Frontier (ECOSUR), the Autonomous University of Chiapas (UNACH), the National Institute of Research on Forestry, Agriculture and Livestock Raising (INIFAP) and the National Commission of Protected Natural Areas (CONANP).

The goal was to create a master plan for cattle raising and environment for the state of Chiapas which would stimulate conversion of extensive cattle raising to environmentally friendly, intensive, integrated silvopastoral systems. In 2004, the first steps of a project oriented to strengthening local capabilities for innovation were implemented. Academics, governmental agencies and producers jointly implemented innovative silvopastoral systems. From 2004-2010, 5 phases in the process of development of silvopastoral systems have been successfully carried out and have helped producers to increase their rate of establishment of fodder trees in 
Table 6: Chronological synthesis of the process of development of silvopastoral systems in the community Tierra Nueva, in the "El Ocote" Biosphere Reserve, Chiapas, Mexico

\begin{tabular}{|c|c|}
\hline Years & Description \\
\hline \multirow[t]{2}{*}{ 2004-05 } & Initial project with 22 producers (SIINV-UNACH, ECOSUR, UNACH, INIFAP) \\
\hline & First demonstrative plot with a Gliricidia sepium protein bank ( $1.8 \mathrm{ha})$ \\
\hline \multirow[t]{3}{*}{2005} & Social, economic and environmental study (SEMARNAT/CONANP) \\
\hline & Workshop on management of protein banks (SEMARNAT/CONANP) \\
\hline & Planting of 12,000 fodder trees in 22 plots (total of $3 \mathrm{ha}$ ) \\
\hline \multirow[t]{4}{*}{2006} & Training of producers in hygienic-sanitary management of animals (SEMARNAT/CONANP) \\
\hline & Integral management of fodder plants (SEMARNAT/ CONANP) \\
\hline & Planting of 8,000 fodder trees in 22 plots (total of 3 ha) \\
\hline & Establishment of the 1 st group of environmental cattle raisers in a community assembly \\
\hline \multirow[t]{6}{*}{2007} & Study of sustaining capacity of pasture units (SEMARNAT/CONANP, ECOSUR) \\
\hline & Formation of the outreach unit in order to transition from conventional to organic cattle raising (UNACH) \\
\hline & Training of producers in sustainable technologies and strategies of agricultural diversification (UNACH) \\
\hline & Planting of 44,000 fodder tree seedlings in 22 plots of $1 / 2$ ha each (total of $11 \mathrm{ha}$ ) (SEMARNAT/CONANP) \\
\hline & Establishment of 22 cut grass plots (Pennisetum sp.) (total of 10 ha) \\
\hline & Organization of 30 new producers of Tierra Nueva to replicate the silvopastoral project \\
\hline \multirow[t]{9}{*}{2008} & Reproduction of the project within the community with the new group of 30 producers (Mesoamerican Biological Corridor) \\
\hline & Formation of the second group of environmental cattle raisers in Tierra Nueva \\
\hline & Setup of community tree nurseries through field schools \\
\hline & Establishment of three community tree nurseries for production and planting of 25,000 fodder tree seedlings \\
\hline & Official registration of the first environmental cattle raisers group \\
\hline & Setup of 22 silvopastoral plots for cattle management by the environmental cattle raisers I group (SEMARNAT/CONANP) \\
\hline & Acquisition of scale for weighing animals (SEMARNAT/CONANP) \\
\hline & Acquisition of 13 fodder mills (SEMARNAT/CONANP) \\
\hline & $\begin{array}{l}\text { Invitation of } 6 \text { new producers to participate in a research project (FOMIX-COCYTECH); these producers currently make up the 3rd group. } \\
\text { Setup of } 27 \text { silvopastoral plots by the second environmental cattle raisers group }\end{array}$ \\
\hline \multirow[t]{4}{*}{2009} & Project for intensification of cattle raising with the second environmental cattle raisers group (mesoameric an biological corridor) \\
\hline & Documentation of the entire project (UVD-UNACH, ECOSUR) \\
\hline & Reproduction of the project with two new nearby communities \\
\hline & Setup of 46 silvopastoral plots in the two new communities \\
\hline 2010 & Improvement to infrastructure of the silvopastoral plots (ECOSUR-FORDECYT) \\
\hline
\end{tabular}

conventional cattle raising systems. Application of these phases could help to resolve the low rates of planting fodder trees in other regions (Mekoya et al., 2008). The 5 phases of this process are:

Introduction and establishment of a demonstration plot: A variety of social actors established a protein bank with Cocoite trees (Gliricidia sepium). Based on the Field schools methodology, this protein bank served as a demonstration plot to train producers in establishing and managing these trees. Participating producers later had the opportunity to practice what they learned in their own plots.

Training and research: Through continuous training, producers improved their abilities in intensive, integrated, sustainable management of silvopastoral systems which includes silvopastoral designs, intensive pasture management, management of protein banks with cut grass Pennisetum sp., supplementation and prevention of infectious cattle diseases.

Formation of new producer groups: The success of the first group of producers in establishing silvopastoral systems motivated other producers of the same community who had not initially participated to get involved. This led to the formation of two new producer groups who joined process of developing silvopastoral systems. Those of the first group participated in training the new members.

Financing infrastructure and equipment: Innovation of silvopastoral systems is currently leading to semiintensive management of cattle raising. It has been necessary to solicit resources from government institutions in order to improve basic infrastructure (construction of rustic stables) and equipment (scale, fodder mill, etc.).

Improvement and diffusion of innovative silovpastoral systems: Based on successful establishment of silvopastoral systems in Tierra Nueva, the producer groups have been visited by representatives of other nearby communities interested in implementing such silvopastoral systems. This has helped to increase implementation of silvopastoral systems in several neighboring communities. In Chiapas as in other regions of Mexico, a variety of intensive silvopastoral systems are 
being fomented. The principal limiting factor of development of silvopastoral systems is that woody fodder species currently cultivated have not been evaluated in all their stages of development. Occasional, incomplete and separate evaluations do not provide sufficient knowledge for overcoming difficulties in management or taking advantage of the potential of the species in each stage of the process of research and development of silvopastoral systems. There is a need for studies of natural (native) or naturalized (adapted) promissory herbaceous and woody species which fully address each stage of this process (Jimenez-Ferrer et al., 2005; Nahed et al., 2003). Evaluation of the level of progress by identifying limits, potentials and opportunities observed in each stage is part of the development process and will allow for continuing or re-evaluating faulty aspects.

Silvopastoral systems follow the principals of organic or ecological cattle raising due to the fact that such cattle raising is developed in production systems based on pasturing which allow for closing the soil-plant animal cycle in a natural and integrated manner while conserving the environment and biodiversity, favoring animal wellbeing, avoiding use of agrochemicals and offering consumers animal products of high organoleptic, nutritional and hygienic-sanitary quality (IFOAM, 2005; Pimentel et al., 2005). According to this logic, the transition of agroforestry systems with an animal component toward organic cattle raising is beginning to be promoted in Chiapas (Nahed et al., 2009).

\section{CONCLUSION}

Producer knowledge as well as chemical analysis of ruminal degradability indicates presence of promissory shrub and tree species for development of silvopastoral systems in the study area; particularly L. collinsii and G.ulmifolia and the fruits of E. cyclocarpum and G. ulmifolia.

The level of acceptance of silvopastoral systems in Tierra Nueva progressed from collective research by a group of producers who established $G$. sepium in a 1.8 ha plot to the incorporation of a second and 3rd group of producers. Currently, G. sepium, L. leucocephala and G. ulmifolia have been established in 22 pastures (for a total of $3 \mathrm{ha}$ ) and 22 additional $1 / 2$ ha plots. Furthermore, 10 ha of cut grass have been established in order to increase carrying capacity of the pasture units. Establishment of silvopastoral systems has led producers to value native woody fodder species, cultivate them and conserve their germplasm. Silvopastoral systems have begun to spread to other communities through producer facilitators who in turn train other producers in their communities to create and manage such systems. To assist this process, it is necessary to implement an integrated program of training, technical assistance and financial support so that regional cattle producers rapidly transition toward silvopastoral systems.

The Field schools methodology has proven to be appropriate for developing producer aptitudes and knowledge in order to implement alternative cattle raising which conserves soil, water, air and local flora and fauna.

\section{REFERENCES}

AOAC, 1995. Official Methods of Analysis. 15th Edn., Association of Official Analytical Chemists, Washington, DC.

Dagang, A.B.K. and P.K.R. Nair, 2003. Silvopastoral research and adoption in Central America: Recent findings and recommendations for future directions. Agroforestry Syst., 59: 149-155.

Delgado, C., M. Rosegrant, H. Steinfeld, S. Ehui and C. Courboys, 1999. Livestock to 2020: The next food revolution. Food Agriculture and the Environment Discusion Paper 28. Washington, DC USA. http://www.fao.org/ag/againfo/resources/document s/lvst2020/20201.pdf.

Esponda, J.M., 1988. Practical handbook of new mexican rancher. Ministry of Economic Development, Mexico, pp: 133.

Gillham, B., 2005. Research Interviewing: The Range of Techniques. McGraw Hill Education, Berkshire, England.

Guevara, H.F., T. Aleman, T. Fuentes and S. Sanchez, 2003. Local capabilities in the generation and dissemination of agricultural knowledge: Exploring the methodology ECA. LEISA Agroecol. J., 19: 8-10.

Guevara-Hernandez, F., R. Pinto-Ruiz, H. Gomez-Castro and F.J. Medina-Jonapa, 2008. Local perceptions on empowerment and development in a remote village of Chiapas, Mexico. Tailoring Biotechnol. J., 4: 71-94.

IFOAM, 2005. Norms for Organic Production and Processing. Version 2005, The International Federation of Organic Agriculture Movements, Germany.

Jimenez-Ferrer, G., J. Nahed-Toral, T. Aleman-Santillan, B. Ferguson, L. Soto-Pinto, M. Ibrahim and F. Sinclair, 2005. Local Capabilities Development and Silvopastoral Intervention in Chiapas, Mexico. In: Silvopastoralism and Sustainable Land Management, Mosquera-Losada, M.R., J. McAdam and A. Rigueiro-Rodriguez (Eds.). CAB International, Walling ford, UK., pp: 402-403. 
Kaitho, R.J., 1997. Nutritive value of browses as protein supplements to poor quality roughages. Doctoral Thesis, Department of Animal Nutrition, Wageningen Agricultural University, The Netherlands.

Khazaal, K., J. Boza and E.R. Orskov, 1994. Assesment of phenolics-related antinutritive effects in mediterranean browse: A comparacion between the use of the in vitro gas production technique with or without insoluble polyvinylspolypyrrolidone or nylon bag. Anim. Feed Sci. Tech., 49: 133-149.

Leng, R.A., 1986. Drought Feeding Strategies: Theory and Practice. Penambul Books, Armidale, NSW Australia, pp: 139.

Lopez-Tirado, Q. and J.G.W. Jones, 1991. A simulation model to assess primary production and use of Bouteloua gracilis Grasslands. Part IIexperimentation. Agric. Syst., 35: 209-227.

Mahadevan, P., 1984. Education of Livestock Producers and Agents of Change in the Use of New Technology. In: World Animal Science: Development of Animal Production Systems, A-2, Nestel, B. (Ed.). Elsevier, The Netherlands, pp: 107-127.

Mannetje, L.'t., 1978. Measuring Quantity of Grassland Vegetation. In: Measurement of Grassland Vegetation and Animal Production, Mannetje, L.'t. (Ed.). Commonwealth Agricultural Bureaux, Great Britain, pp: 63-95.

Mehrez, A.Z. and E.R. Orskov, 1977. A study of artificial fiber bag technique for determinin the digestibility of feeds intherumen. J. Agric. Sci., 88: 645-650.

Mekoya, A., S.J. Oosting, S. Fernandez-Rivera and A.J. van der Zijpp, 2008. Farmers perceptions about exotic multipurpose fodder trees and constraints to their adoption. Agroforestry Syst., 73: 141-153.

Minjauw, B., H.G. Muriuki and D. Romney, 2002. Developmemt of farm field school methodology for small-holder dairy farmers in Kenya. Proceedings of the International Learning Workshop on Farmer Field School (FFS): Emerging Issues and Challenges, Oct. 21-25, Yogyakarta, Indonesia, pp: 1-13.

Mupangwa, J.F., T. Acamovic, J.H. Topps, N.T. Ngongoni and $\mathrm{H}$. Hamudikuwanda, 2000. Content of soluble and bound condensed tannins of three tropical herbaceous forage legumes. Anim. Feed Sci. Technol., 83: 139-144.

Nahed, J., A. Sanchez, D. Grande and F. Perez-Gil, 1998. Evaluation of promissory tree species for sheep feeding in the highlands of Chiapas, Mexico. Anim. Feed Sci. Tech., 73: 59-69.
Nahed, J., T. Aleman, G. Jimenez, Q. Lopez-Tirado and D. Grande et al., 2003. Study for the Development of Agroforestry Systems: Experiences in the Maya-Tzotzil Region. In: Agroforestry for Livestock Production in Latin America-II, Sanchez, M.D. and M. Rosales (Eds.). FAO, Rome, pp: $343-357$.

Nahed, J., L. Garcia-Barrios, Y. Mena and J.M. Castel, 2006. Use of indicators to evaluate sustainability of animal production systems. Options Mediterraneennes Serie A, 70: 205-212.

Nahed, J., P.J. Calderon., J.R. Aguilar, B. Sanchez-Munoz and J.L. Ruiz-Rojas et al., 2009. Approximation of the agroforestry systems of three micro-regions of Chiapas to organic production model. Avances de Inv. Agrop., 13: 45-58.

Nair, P.K.R., 1993. An Introduction to Agroforestry. 2nd Edn., Kluwer Academic Publisher, Dordrecht, ISBN: 0792321340.

Perez, S.E., 2006. Characterization of silvopastoral systems and their socioeconomic impact on cattle producers in Copan, Honduras. Master Thesis, Tropical Agriculture Research and Teaching, Turrialba, Costa Rica.

Pimentel, D., P. Hepperly, J. Hanson, D. Douds and R. Seidel, 2005. Environmental, energetic and economic comparisons of organic and conventional farming systems. BioScience, 55: 573-582.

Pinto, R., H. Gomez, A. Hernandez, F. Medina and B. Martinez et al., 2006. Uses and nutritional characteristics of fodder trees of three livestock regions in Chiapas, Mexico. Proceedings of the 3rd National Meeting on Agro and Silvopastoral Systems. (NMASS'06), Universidad Autonoma Metropolitana, Mexico City, pp: 122-128.

Pinto, R.R., 1995. Mineral supplementation for grazing heifers in central Chiapas. Master Thesis, Animal Science Department, Universidad Autonoma de Chapingo, Chapingo, State of Mexico, Mexico.

Rittner, U. and J.D. Reed, 1992. Phenolics and in-vitro degradability of protein and fibre in West African browse. J. Sci. Food Agric., 58: 21-28.

Russo, R.O., 1996. Agrosilvopastoral Systems: A practical approach toward sustainable agriculture. J. Sustainable Agric., 7: 5-16.

SAGARPA, 2003. Agricultural information system consultation. Ministry of Agriculture, Livestock, Rural Development, Fisheries and Food, Mexican Government. 
Speeding, C.R.W., 1995. Sustainability in animal production systems. Anim. Sci. (British), 61: 1-8.

Steinfeld, H., 2002. Increasing global demand for animal products. Responding to the Increasing Global Demand for Animal Products: Programme and Summaries of an International Conference Organised by BSAS, ASAS and MSAP, Merida. Mexico, November 2002.
Trlica, M.J. and L.R. Rittenhouse, 1993. Grazing and plant performance. Ecol. Appl., 3: 21-23.

Vasquez, S.M.A., M.I. March, M.M. Ramos and C.A. Gutierrez, 1996. Socioeconomic Characteristics of the Rainforest El Ocote. In: Conservation and Sustainable Development in the Rainforest El Ocote, Chiapas, Vazquez, S.M.A. and M.I. March (Eds.). ECOSUR/CONABIO, Mexico, pp: 263-307. 